\title{
Pelagic ecosystem response to climate variability in the Pacific Ocean off Baja California
}

\author{
Gilberto Gaxiola-Castro' ${ }^{1}$, Bertha E. Lavaniegos ${ }^{1}$, Antonio Martínez²,
}

Rubén Castro ${ }^{2}$, T. Leticia Espinosa-Carreón ${ }^{3}$

${ }^{1}$ Centro de Investigación Científica y Educación Superior de Ensenada. Departamento de

Oceanografía Biológica. Carretera Ensenada-Tijuana No. 328. Fracc. Zona Playitas.

Ensenada, Baja California, México. C.P. 22860. ${ }^{2}$ Universidad Autónoma de Baja

California. Facultad de Ciencias Marinas. Kilómetro 107 carretera Tijuana-Ensenada. Ensenada, Baja California, México. C.P. 22810. ${ }^{3}$ Centro Interdisciplinario de Investigación para el Desarrollo Integral Regional (CIIDIR) Unidad Sinaloa-IPN. Blvd. Juan de Dios

Bátiz Paredes \#250. Col. San Joachin. C.P. 81101. Guasave, Sinaloa, México.

\section{Introduction}

The oceans enclose 72 percent of the Earth's surface, controlling the global deliveries of heat and freshwater which drive our climate and weather. In turn, the enormous and varied oceanic ecosystems are affected by the ocean climate, generating changes mainly in the upper part of the water column which can be detected as response to this variability. In particular, the Pacific Ocean environment is affected by changes in the world climate, responding to seasonal, interannual, and interdecadal variability, as well as El Niño-La Niña cycles.

The California Current System (CCS) located in the northeastern Pacific Ocean, is one of the largest marine ecosystems of the world, with physical and biological mechanism forced by regional (coastal upwelling, eddies, wind driven currents), and large scale processes (e.g. El Niño-La Niña cycles). One example of these large scale processes affecting the CCS region was the anomalous intrusion of Subartic fresher water into during the 2002-2006 periods, which disturb the California Current (CC) ecosystems from Canada to Mexico (Bograd \& Lynn, 2003; Durazo et al., 2005; Durazo, 2009; Freeland et al., 2003; Gaxiola-Castro et al., 2008; Lavaniegos, 2009). The ocean climate response of the CC region off Baja California is particularly significant because this is a transitional ocean basin, highly influenced by the equatorward flow of Subartic waters mainly during spring and summer (Durazo \& Baumgartner, 2002), and by subtropical signatures triggered by poleward flows mostly during late summer and autumn (Bograd et al., 2000; Durazo, 2009). Moreover, CCS off Baja California is a useful region to understand large and mesoscale ocean climate effects on physical and biological variability of the marine environment, and for instance of climate change. 
In this contribution we examine the associations between large-scale temporal climate physical forcing and the plankton variability off Baja California. The pelagic ecosystem off Baja California has been influenced by large scale processes like the 1997-1998, and 20082009 El Niño events, which were characterized by low chlorophyll, high sea surface height, high surface salinity, and high sea surface temperature, with opposite conditions during the 1998-1999 and 2007-2008 La Niña events (Espinosa-Carreon et al., 2004; McClatchie et al., 2009). Seasonal and interannual patterns are also observed off Baja California, with a maximum of phytoplankton Chlorophyll- $a$ occurring in spring, as a result of the phytoplankton growth in response of the seasonal maximum of upwelling-favorable winds (Espinosa-Carreon et al. 2004; Perez-Bruinus et al. 2007). Zooplankton biomass is larger in summer and autumn, characterized by abundance of copepods, euphausids, and other minor groups, higher abundance of salps during the 1997-1998 El Niño event, and by jelly fish and ctenophores abundances in April 2009 (Lavaniegos et al., 2010).

The main objectives of this chapter are to describe the general conditions in the CCS off Baja California coast from 1997-2010, reviewing the governing ocean climate and physical forcing at different time and scales, that might have influenced the pelagic ecosystem of the study region.

\section{Climate conditions off Baja California}

Northeast Pacific Ocean atmospheric circulation is dominated by the North Pacific High Pressure center (NPH). In February, this pressure system is weak and located $\sim 25^{\circ} \mathrm{N}-130^{\circ} \mathrm{W}$ off Baja California coast. During summer the NPH migrates near of $\sim 38^{\circ} \mathrm{N}-145^{\circ} \mathrm{W}$, where it reaches the maximum values. Between spring and summer the strong pressure gradient generate high equatorward upwelling favorable winds between northern California and the Baja California coast (Huyer, 1983; Strub et al., 1987; Strub \& James, 2002; Perez-Brunius et al., 2007; Castro \& Martinez, 2010). In the vicinity of Baja California coast the wind is highly persistent with a south-southeast direction. Wind speeds are stronger and less variables in spring and summer than during autumn and winter. Annual harmonic of the wind has small amplitude, with low $(<30 \%)$ explained variance.

In general, high frequencies (order of days) play a dominant role in the region. Interannual variability of the NPH is frequently linked with negative (positive) sea level pressure anomalies during El Niño (La Niña), which produces weak, and/or reversal winds during El Niño and strong equatorward winds during La Niña episodes (Lynn et al., 1998; Schwing et al., 2002; Peterson \& Schwing, 2003). Off Baja California coast the influence of the El Niño conditions produces low chlorophyll, high SSH, and high SST, with opposite conditions during La Niña (Espinosa-Carreon et al., 2004; Durazo, 2009). During 2002 a weak El Niño condition was observed on southern California and Baja California waters, at the same time that anomalous influence of subarctic waters in the California Current System was evident (Schwing et al., 2002; Bograd \& Lynn, 2003; Durazo et al., 2005).

The roll of the wind stress curl has not received much attention in this region, and their contribution to upwelling process it is not clear. Some general characteristics of the wind field along the Baja California Peninsula are given in Castro \& Martinez (2010), where the potential importance of the curl wind stress on the area close to the coast along the Baja California Peninsula is suggested. Next to the shore, the coast affects wind intensity and decay, inducing positive curl (and then Ekman pumping) contributing to the injection of 
nutrients to the surface (Cappet et al., 2004). Chelton et al. (2007) discuss the relevance of the wind stress curl and its divergence and their relation to ocean sea surface temperature.

\section{Data and Methods}

In this chapter we examine satellite observations on the Pacific Ocean off Baja California Peninsula coast, with emphasis on interannual variability patterns. The analysis was made with wind stress data, sea surface height (SSH) anomaly, and sea surface temperature (SST). The wind data were obtained from PODAAC-CCMP product with spatial resolution $0.25^{\circ} \mathrm{x}$ $0.25^{\circ}$ described by Atlas et al. (1996) and Hoffman (1984). Sea surface height was obtained by Ssalto/Duacs and distributed by AVISO (http://www.aviso.oceanobs.com/duacs/). Sea surface temperature data (SST) was obtained from the PODAAC-AVHRR (http:// podaac.jpl.nasa.gov). All the satellite data covers the time period between January1996 to December-2007, and were processed to obtain weekly time series, and low passed filtered with a 400 days cutoff filter. The wind stress $\left(\mathrm{N} \mathrm{m}^{-2}\right)$ was calculated with the equation

$$
\tau=\rho C_{d}|V| V
$$

where $\rho$ is the air density $\left(\mathrm{kg} \mathrm{m}^{-3}\right), \mathrm{C}_{\mathrm{d}}$ is the drag coefficient (nondimensional and function of the wind speed magnitude), $\mathrm{V}$ is the vector velocity and $|\mathrm{V}|$ its magnitude. Multivariate ENSO Index (MEI; http://www.esrl.noaa.gov/psd/data/) is compared with standardized anomalies of satellite variables described above.

Weekly remote sensed composite imagery of chlorophyll (CHL) were obtained from September 1997 to February 2010 for the region off Baja California between $22^{\circ} \mathrm{N}-33^{\circ} \mathrm{N}$ and $112^{\circ}-120^{\circ} \mathrm{W}$ (Fig. 1). SeaWiFS (Sea Viewing Wide Field of View Sensor) ocean color data were downloading from http://oceandata.sci.gsfc.nasa.gov/SeaWiFS/Mapped/ 8Day/chlor/ with 9-km resolution for the last re-processing version of December 2009. Use of the geometric mean and log transformation follow the assumption that oceanic biooptical data are lognormal distributed. We obtained the fraction of observations available from 540 weekly images. For each of the three selected areas (north, central, and south; see title of figure 1), the temporal mean, as well as the annual and semiannual harmonics were removed. These were calculated by fitting the time series to mean plus annual and semiannual harmonics:

$$
F(\bar{x}, t)=A_{0}(\bar{x})+A_{1}(\bar{x}) \cos \left(w t-\phi_{1}\right)+A_{2}(\bar{x}) \cos \left(2 w t-\phi_{2}\right)
$$

where $A_{0}, A_{1}$, and $A_{2}$ are the temporal mean, annual amplitude, and semiannual amplitude for each time series at each pixel; $w=2 \pi / 365.25$ is the annual radian frequency; $\varphi_{1}, \varphi_{2}$ are the phases of annual and semiannual harmonics respectively; and $t$ is the time (as year-day). 


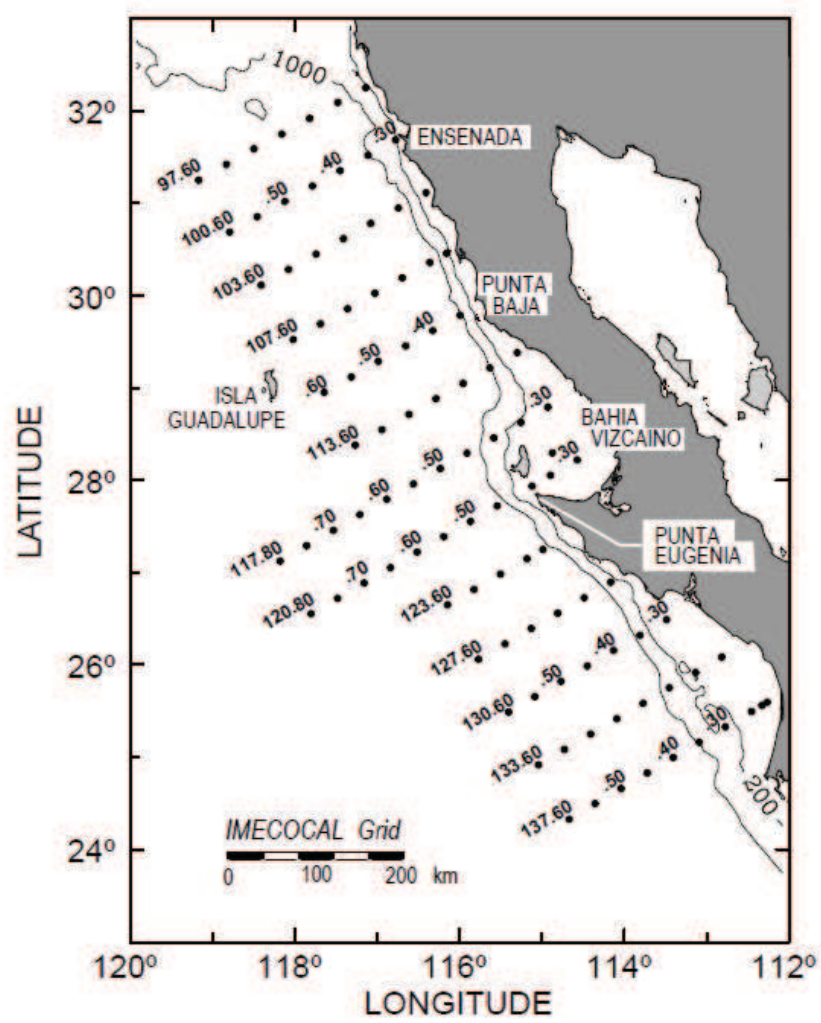

Fig. 1. IMECOCAL station grid off Baja California, México surveyed from September 1997 to April 2010. Line and station number follow the CalCOFI nomenclature. Line 97 was only covered during spring season cruises. Chlorophyll- $a$, and SeaWIFS imagery data analyses were separated in three regions: north (lines 100 to 110), central (lines 113 to 123), and south (lines 127 to 137). Also, zooplankton volume means were obtained of data grouped in regions named as north (lines 100-110), and central (lines 113-137).

We use IMECOCAL (Spanish acronym of Mexican Oceanographic Investigations of the California Current) research program data collected from 1997-2010 surveys, together with CalCOFI (California Cooperative Fisheries Investigations) 1950-2009 data, to illustrate the temporal links between lower trophic biological levels and large-scale climatic processes in the northeastern Pacific Ocean off Baja California. Quarterly sampling routine of the IMECOCAL cruises conducted on the Mexican RV Francisco de Ulloa includes CTD/Rossete casts (conductivity, temperature, depth) to $1000 \mathrm{~m}$, depth permitting; also water samples from the upper $200 \mathrm{~m}$ collected in 5-liter Niskin bottles to determine phytoplankton Chlorophyll- $a$, and zooplankton tows were analyzed. The present study includes information from 45 cruises performed between September 1997 and April 2010 through a station grid of 92 stations (Fig. 1).

Water column phytoplankton Chlorophyll- $a$ was determined from 1-liter discrete seawater samples, filtered onto Whatman GF/F filters, following the fluorometric method (Yentsch \& 
Menzel, 1963; Holm Hansen et al., 1965) with modifications of Venrick \& Hayward (1984). Integrated $100 \mathrm{~m}$ water column Chlorophyll- $a$ anomalies were calculated for the period 1998-2010 removing the long-term seasonal mean. Since the IMECOCAL domain is characterized by different hydrographic provinces (Subarctic north of $28^{\circ} \mathrm{N}$; Subtropical and tropical south of $28^{\circ} \mathrm{N}$ ), regional averages of Chlorophyll- $a$ anomalies for three separated regions were calculated.

During the IMECOCAL surveys zooplankton was collected with a bongo net of $505 \mu \mathrm{m}$ mesh-width doing double oblique hauls in the upper $210 \mathrm{~m}$ or from $10 \mathrm{~m}$ above the bottom to the surface at shallow stations. The diameter of the net was $61 \mathrm{~cm}$ before October 2001, and then it was replaced by one of $71 \mathrm{~cm}$. The volume of water strained was measured with a flow meter in the mouth of the net. Samples were preserved with $4 \%$ formalin and sodium borate. A total of 3044 zooplankton samples were processed for displacement volume determination with a graduate cylinder one month after the end of each cruise. Taxonomic identification of major taxa were done selecting 1215 nighttime samples from oceanic stations (>200 m depth). Here only data of copepods and euphausiids are presented separately, while the rest of the taxa were combined in the category of other zooplankton. They were counted from a fraction $(1 / 8,1 / 16$, or $1 / 32)$ of the original sample. Zooplankton biomass and abundance were log-transformed to normalize data. Biomass and abundance anomalies for the period 1997-2008 were estimated removing the long-term seasonal mean. Time series of abundance anomalies for copepods and euphausiids were subject to linear regression analyses.

Data of daily upwelling indices (UI) from www.pfeg.noaa.gov/products/products.html, were also used to illustrate the variability in coastal upwelling activity. The data were obtained for two sites: off Punta Baja $\left(30^{\circ} \mathrm{N}, 119^{\circ} \mathrm{W}\right)$ and off Punta Eugenia $\left(27^{\circ} \mathrm{N}, 116^{\circ} \mathrm{W}\right.$; see figure 1). UI monthly means (and standard deviations) were estimated. Further, UI anomalies were calculated removing long-term monthly means from the period 1997-2008. In addition, we used oceanic climate indices (MEI, Multivariate ENSO Index; http://www.esrl.noaa.gov/psd/people/klaus.wolter/MEI/; PDO, Pacific Decadal Oscillation; http://jisao.washington.edu/pdo/PDO.latest; NPGO, North Pacific Gyre Oscillation; http://ocean.eas.gatech.edu/npgo/), which are contrasted with integrated water column Chlorophyll- $a$ anomalies, computed from the IMECOCAL hydrographic data.

\section{Physical Forcing Analysis}

The response to the forcing at interannual variability scales off the Baja California coast is evident from the time series on figure 2. In this figure, the wind stress magnitude, wind stress curl, SST (Sea Surface Temperature) and SSH (Sea Surface Height) anomalies were averaged on the overall IMECOCAL area, and compared with the MEI. Anomalies were computed averaging spatially all data over the area on figure 4, subtracting the temporal mean and dividing by the standard deviation. The correlation coefficient $(\mathrm{r})$ between wind stress (magnitude and curl) and MEI was very low ( $\mathrm{r} \sim 0.1)$. Negative anomalies of the wind stress occurred during 1997, 2002, and 2004-2005, coinciding roughly with positive values of MEI, which could be associated to El Niño conditions and relatively weak winds on the northeastern Pacific (Peterson \& Schwing, 2003).

The strength of the wind anomalies showed poor agreement with MEI; for example in 1997, negative anomalies of the wind stress reached values as low as -2.0, while during the 2004 
event were just $\sim-0.7$. Wind positive anomalies were present from 1998 to 2000, matching much of the time with La Niña. At the second half of 2005, high positive wind anomalies were observed between the last part of El Niño 2004-2005 and the transition to negative values of MEI (weak La Niña conditions). Summarizing, the MEI does not represent adequately the wind events off Baja California coast.

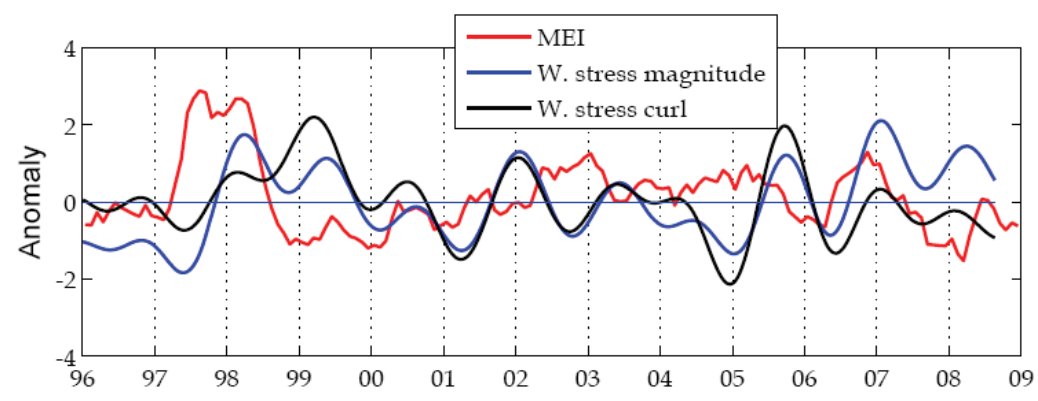

a

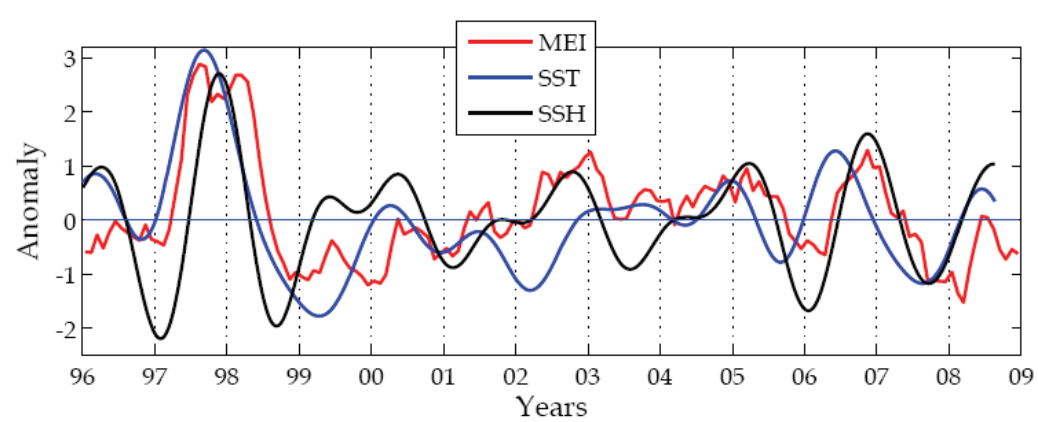

b

Fig. 2. (a) Anomalies of the wind stress magnitude and wind stress curl; (b) SST (Sea Surface Temperature) and SSH (Sea Surface Height). Multivariate El Niño Southern Oscillation Index (MEI) is included in both figures as reference.

Interannual SST anomalies were better correlated with the MEI than the wind (Fig. 2). The correlation (at 0 lag) between SST and MEI was relatively high $(\mathrm{r}=0.66)$. The most remarkable SST events were during 1997-1998, and 2006 corresponding to El Niño conditions, where both MEI and SST showed positive anomalies (Espinosa-Carreon et al., 2004). Negative SST anomalies occurred during 2002-2003 with positive MEI values, which possibly was related with a strong incursion of subartic waters to the region (Durazo et al., 2005).

SST negatives anomalies were evident during La Niña episodes, between winter 1998 and 2000-2001, and remained until 2003. A shift between anomalies of SST-MEI is evident; with SST anomalies preceding MEI (figures 2, 4a). This lag has been reported by Lynn et al. (1998). SSH anomalies were well correlated with MEI $(r=0.52)$, except during the La Niña conditions (1999-2000) (Fig. 3). During La Niña 1999-2000 the MEI and SST showed negative values, while SSH was positive, which is not consistent with a thermal expansion. 


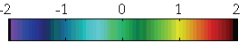

(a) $\operatorname{sst}\left({ }^{\circ} \mathrm{C}\right)$

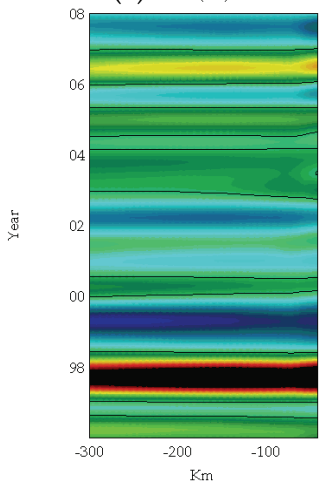

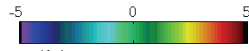

(b) $\operatorname{ssH}(\mathrm{cm})$

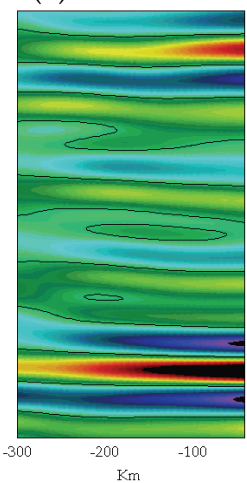

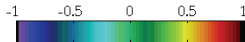

(c) $\operatorname{ROT}\left(\mathrm{Nm}^{-3}\right) \quad \times 10^{-7}$

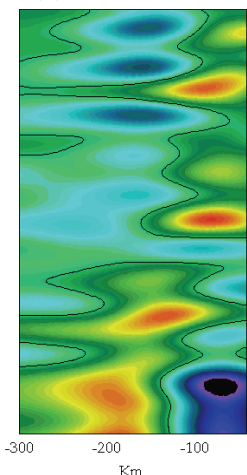

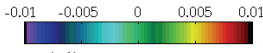

(d) $|\tau|\left(\mathrm{Nm}^{-2}\right)$

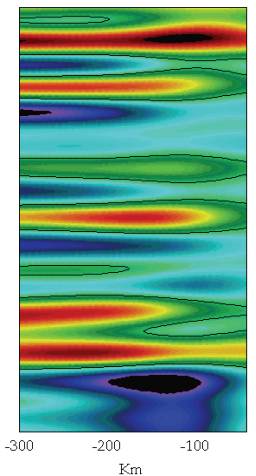

Fig. 3. Hovmuller diagram: (a) SST; (b) SSH; (c) wind stress curl magnitude; (d) wind setress curl anomalies. Each variable has been low passed filtered and averaged on the along shore direction. The horizontal axis represent the distance in $\mathrm{km}$ from the coast $($ at $\mathrm{x}=0)$. The vertical axis represents the time beginning in January 1996.

Time response of the Pacific Ocean along the Baja California Peninsula, as observed in figure 3 , shows a lagged relation for each variable. In particular, the positive anomalies of SST (Fig. 3a) clearly preceded positive anomalies of SSH (Fig. 3b) during El Niño years. Casey \& Adamec (2002) found that the relationship between SST-SSH is consistent with thermal expansion related to ENSO, which was proposed before by Leuliette \& Wahr (1999). The lag between SST and SSH is more evident if we relate those variables with some diagnostic index like the MEI. The correlation was made between the MEI and the weekly-unfiltered time series of each variable on every grid point to show the short term lag. SST is somewhat correlated with MEI. The maximum correlation (Fig. 4a) occurs around Punta Eugenia $\left(28^{\circ} \mathrm{N}\right)$. In general the correlation is low (but significant at the $95 \%$ confidence level). The lag between MEI and SST (black contour line in Fig. 4a) shows that SST precedes MEI by 1 to 1.5 months and shows a northward propagation. By the other side, the correlation between SSH and MEI (Fig. 4b) is much higher for the most part of the area. In contrast, the lag shows that the MEI leads SSH by 1.5 months along the coast, and the lag decreases on the offshore direction to 0.5 months. It is important to mention that if the SST and SSH data are lowpassed filtered, the correlation, as expected, will increase significantly, but the short-term lag will be lost.

In addition, figure 3 also shows a rich offshore structure of the wind stress curl (Fig. 3c) and magnitude (Fig. 3d). The wind stress curl is positive most of the time near the coast, and changes sign away from the drop off zone (Castro \& Martinez, 2010). The effect of the wind stress curl seems to be related to SST in such way that when the wind stress curl is weak (negative anomaly in figure 3c) SST increases. Almost two years previous to the 1997-1998 El Niño, the wind stress curl was very weak next to the coast (Fig. 3c), as was the wind intensity (Fig. 3d). In contrast, during the 2002 El Niño, the SST anomaly was negative (colder). There was not a response of SSH, with a positive wind stress curl anomaly next to the coast, and the intensification of the wind magnitude. The 2006 El Niño event produced 
very similar (but moderate) response on SST, SSH, and wind magnitude anomalies to the 1997-1998 event. It is important to notice that the wind magnitude anomalies in figure $3 \mathrm{~d}$ are more intense off the coast, while the wind stress curl has large values near the coast.
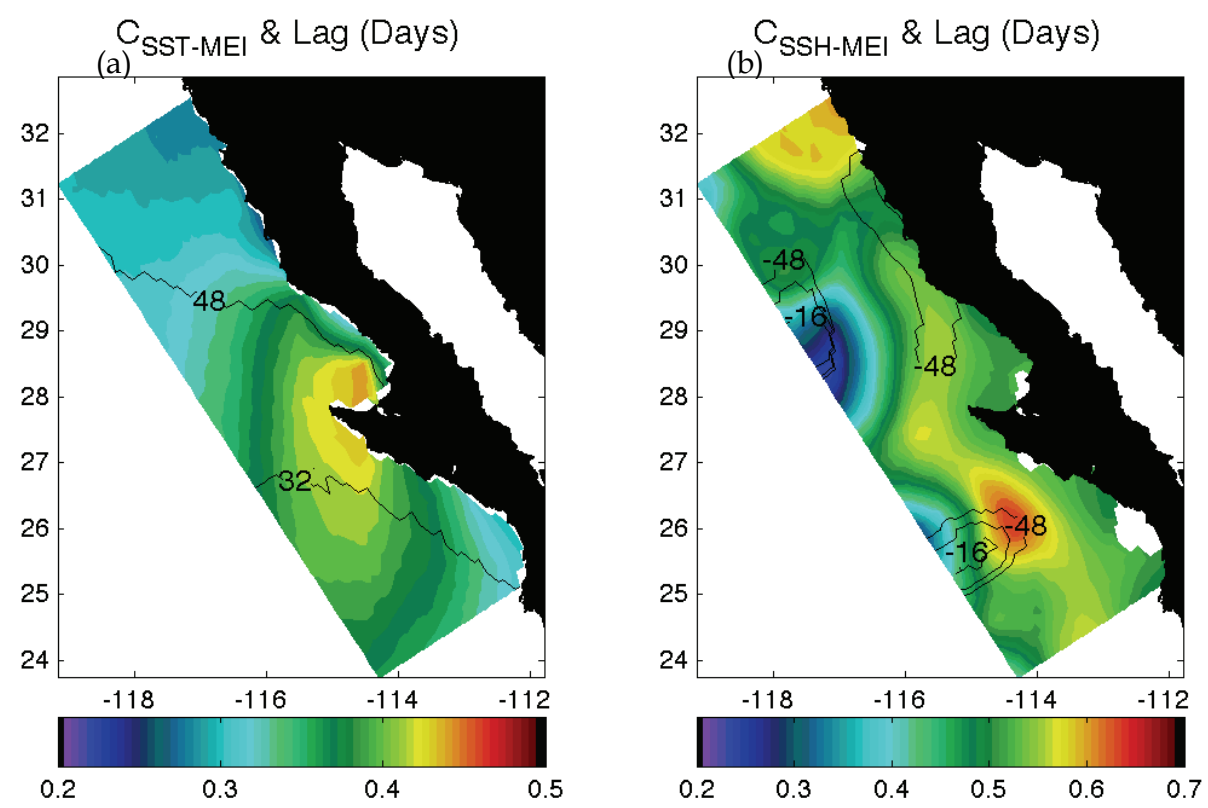

Fig. 4. Correlation between the MEI with SST (a), and MEI with SSH (b) on every grid point. Data cover the period from 1996-2007, without filtered. The black contour-line represents the lag in days.

To investigate a possible dynamical relationship connecting SST and the other analyzed variables, we calculate the zero-lagged time correlation of the low passed filtered data described previosly. The correlations between SST and SSH, wind stress curl $(\nabla \times \tau)$, wind stress major component $\left(\tau_{x}\right)$ and wind stress minor component $\left(\tau_{\mathrm{y}}\right)$ were calculated for every grid point and then averaged on the along-coast direction. Just the significant correlations were considered for the averaging. The black line in figure 5 shows the correlation between SST and SSH.

Largest correlation was on the coast vicinity (offshore distance $\leq 150 \mathrm{~km}$ ). Beyond this point the correlation decaes gradually. The positive sign shows two possible mechanism involved: the upwelling scenario, where sea level and SST decreases; and the thermal expansion scenario, where as the water temperature increases sea level also increases. The latest scenario does not seems to be probable in this analysis since figure 5 shows the zero lag correlation, namely the short term response. The major component of the wind stress $\left(\tau_{x}\right)$ is almost aligned with the shore line. It is well correlated with SST, except near the coast (red line in figure 5). The minor component of the wind stress $\left(\tau_{\mathrm{y}}\right)$, does not show a clear relation 
with SST, and the wind stress curl shows the strongest relation with SST at about $120 \mathrm{~km}$ off the coast.

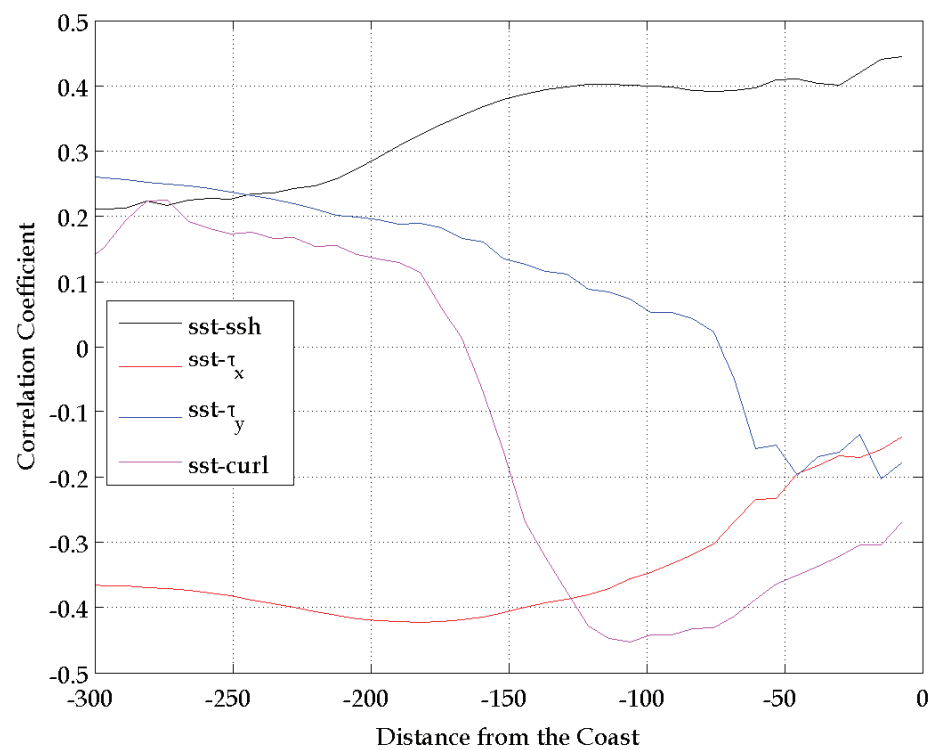

Fig. 5. Time correlation between SST and SSH (black line). Wind stress principal component $\tau_{\mathrm{x}}$ (red line) and minor component $\tau_{\mathrm{y}}$ (blue), and wind stress curl (magenta). The correlation was done for every point and then averaged on the along shore direction.

Near the coast ( $\sim 20 \mathrm{~km}$ off shore), SST is well related with SSH, being the wind stress curl the second dominant forcing. Beyond this point, the dominant forcing is the component of the wind stress parallel to the coast $\left(\tau_{\mathrm{x}}\right)$. The negative sign of the SST- $\tau_{\mathrm{x}}$ correlation indicates upwelling (since the major component is esentially positive), but from figures 3 , and 5 , the SST is mainly related with the wind $150 \mathrm{~km}$ away from the coast. It is clear that the averaged correlation shown in figure 5, fades the local relation between SST, SSH, and the wind. The relevance of the relationships derived from figure 5, is that the dependence of SST on the wind or SSH, can not be sumarized on a single mechanism. The wind stress curl dominates on the wind intensity near the coast. This result implies that Ekman pumping is also important on the near coast area. Ekman pumping could be a possible alternative mechanism to explain the presence of SST anomalies. Cold (warm) SST during La Niña (El Niño) events seems to be in phase with positive (negative) anomalies of the wind stress curl (Fig. 3a,c). Also the role of SSH is important on the coast neighborhood, as it is well correlated with SST. Offshore, the wind component parallel to the coast dominates.

\section{Remote sensed and in situ Phytoplankton Chlorophyll}

The fraction of available remote sensed composite imagery of chlorophyll (CHL) SeaWiFS 1997-2010 data for the region off Baja California (percent of current data in the weekly 
images) show high values $(>80 \%)$ near coastal zone, diminishing offshore, with lowest values $(<50 \%)$ in the southwest region.
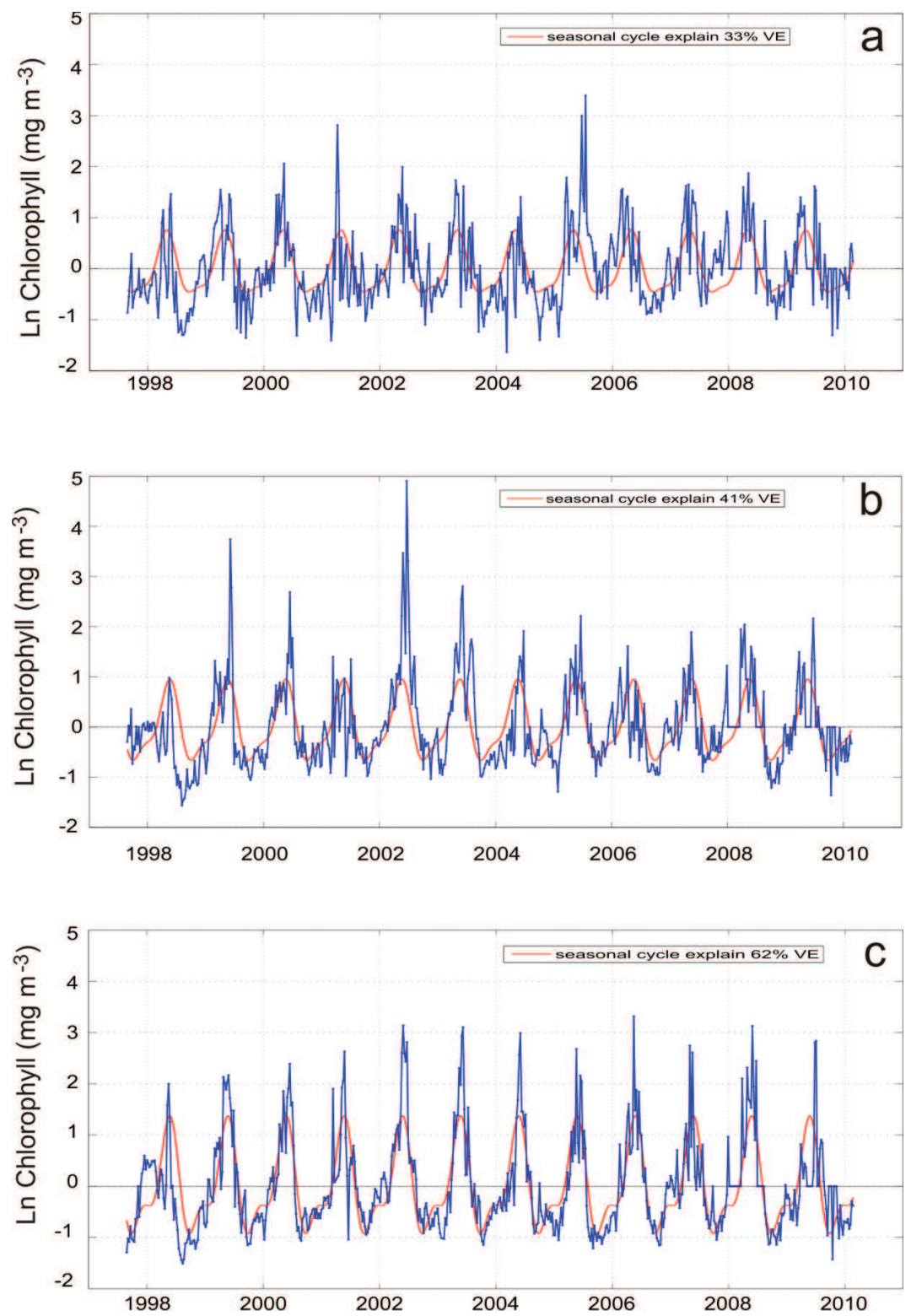

Fig. 6. Time series of log-transformed chlorophyll data (CHL, $\mathrm{mg} \mathrm{m}^{-3}$ ) obtained from SeaWIFS weekly composite imagery for the region off Baja California, México. Red color indicated the adjusted seasonal cycle. In blue color are the CHL time series for the three regions described in figure 1. a) north; b) central; c) south. 

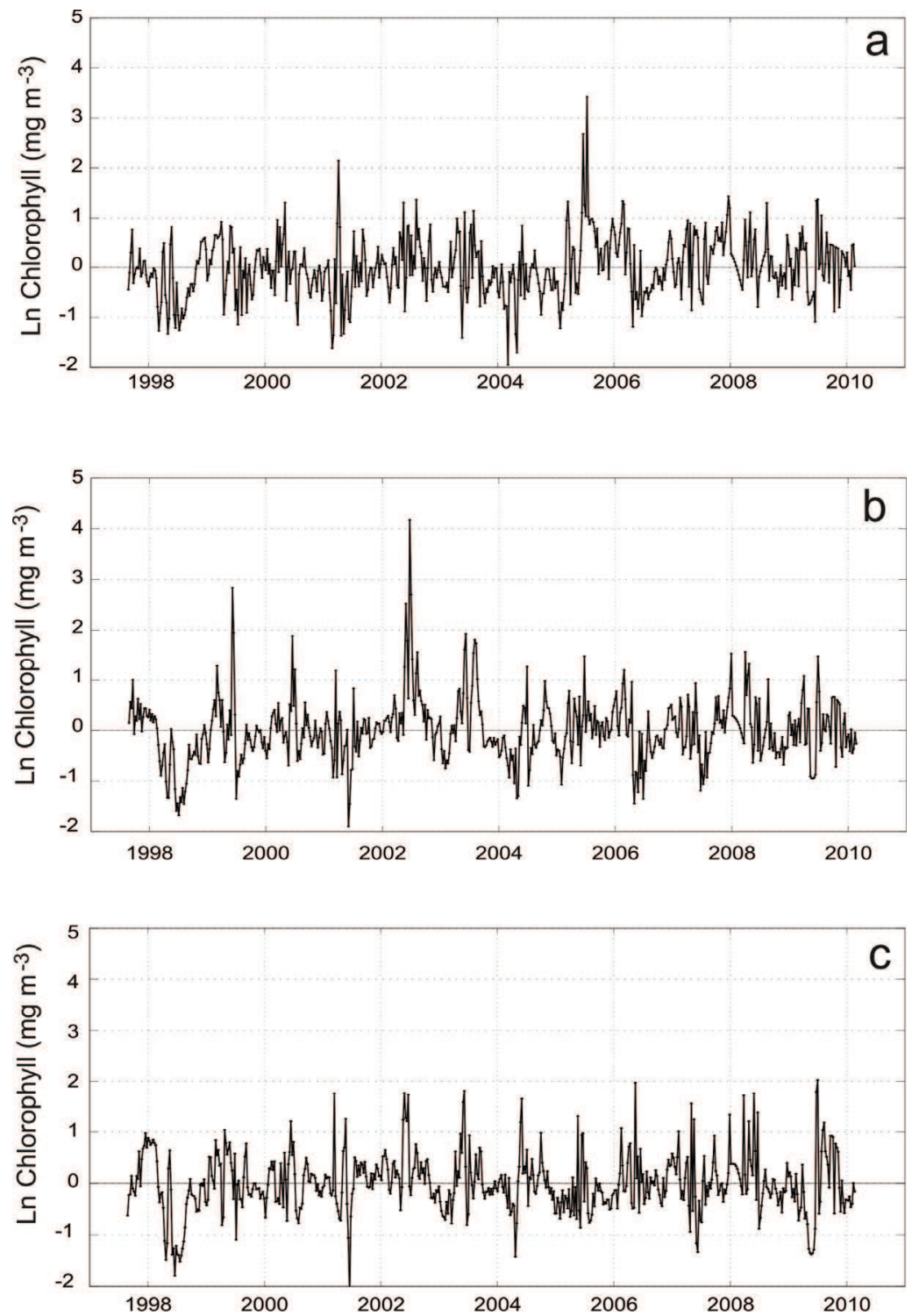

Fig. 7. Time series of log-transformed chlorophyll (CHL) anomalies calculated by subtracting mean seasonal cycles from weekly original SeaWIFS imagery data, collected for the three regions off Baja California described in figure 1. a) north; b) central; c) south.

The variance of CHL explained by the seasonal cycle (\%VE) show some differences at coastal and offshore zones. Offshore Baja California appears to be at least three main processes influencing spatial variability: from $29-33^{\circ} \mathrm{N}$ the $10-40 \% \mathrm{VE}$ is related with the influence of the California Current flowing southward. In the southwest zone the VE was 
$10-30 \%$, probably associated with mesoscale processes as was illustrate before by EspinosaCarreon et al. (2004). The low variance explained $(<10 \% \mathrm{VE})$ should be associated to other different spatially scales processes (data not shown).

For the entire region off Baja California the variance explained by the seasonal cycle increased from northern to southern regions (see figure 1), with $33 \%$ in the north region, $41 \%$ in the central region, and $62 \%$ in the south region (Fig. 6a, b, c). The maximum increase on phytoplankton Chlorophyll-a occurred during spring, as a result of phytoplankton growth in response of seasonal maximum in upwelling-favorable winds (Perez-Brunius et al., 2007; Castro \& Martinez, 2010), transporting inorganic nutrients to the ocean surface and enhancing primary production. Seasonal cycle amplitude increased also from north to south regions, with an annual signal dominating. However, the southern region during winter season shows a raise, which represents an unambiguous semiannual signal.

Satellite chlorophyll diminished at northern and central regions during the 1997-98 El Niño event, without any important decreasing at the southern region. This pattern for the lasted region has been discussed before (Kahru \& Mitchell, 2000; Yoder \& Kennelly, 2003; Espinosa-Carreon et al., 2004), without a comprehensible exposition of the processes implicated. The chlorophyll increase during 2005 at the north region (Fig. 6a), has been associated with coastal upwelling improved through this particular year in the California Current off Baja California (Durazo, 2009; Lavaniegos, 2009).

Baja California central region is a well representative area of the large scale processes influencing this basin (Fig. 6b), generally in the lower trophic pelagic organisms. These effects are mostly apparent during 1998, 2002, and 2003, related with El Niño-La Niña cycles. In the southern region, spring satellite chlorophyll show positive anomalies, except during 1997-1998 (Fig. 6c). In that period with an El Niño influence, CHL time series show an increase on late fall and winter, decreasing in spring season (Fig. 6c).

Interanual time series variability for each region is shown in figure 7 (time series without seasonal cycle). In general, variability of log-transformed chlorophyll shown low values during 1998, without an apparent pattern in the northern region. In 2005 positive CHL anomalies were related with warm and cool conditions respectively (Fig. 7a). In the central region CHL changes from positive to negatives anomalies during 1997-98 El Niño cycles, with positive anomalies associated to the 2002-2003 La Niña cycle (Fig. 7b). The southern region had lower variability, but during 1997-1998 positive anomalies are evident in late fall and winter, and negative during spring and summer. After that, positive CHL anomalies were observed on all spring seasons (Fig. 7c).

Water column integrated phytoplankton Chlorophyll- $a$ anomalies estimated for three regions off Baja California from 1998-2010 were related with the MEI (Multivariate ENSO Index), PDO (Pacific Decadal Oscillation), and NPGO (North Pacific Gyre Oscillation) indices (Fig. 8). In general, chlorophyll anomalies for these three selected regions follow a similar tendency that the NPOG index, except during 2003 and in fewer manners 2004, when the index had positive values and the chlorophyll had negative anomalies (Fig. 8c, d, e, f). According with Di Lorenzo et al. (2008) the NPGO index response to changes in the sea surface height variability, and measure alterations of the North Pacific Ocean gyres, related with atmospheric forcing along the coast. A positive NPGO index value would indicate suitable oceanic conditions for wind-driven upwelling and horizontal advection enhancement, increasing surface nutrient concentration and for instance the phytoplankton growth. However, long-term phytoplankton variability in the regions off Baja California 
during the period from 2003 to 2007 appears to respond more properly to decadal forcing changes (PDO index) with an inverse trend between this ocean climate variability index and the phytoplankton biomass (Gaxiola-Castro et al., 2008).

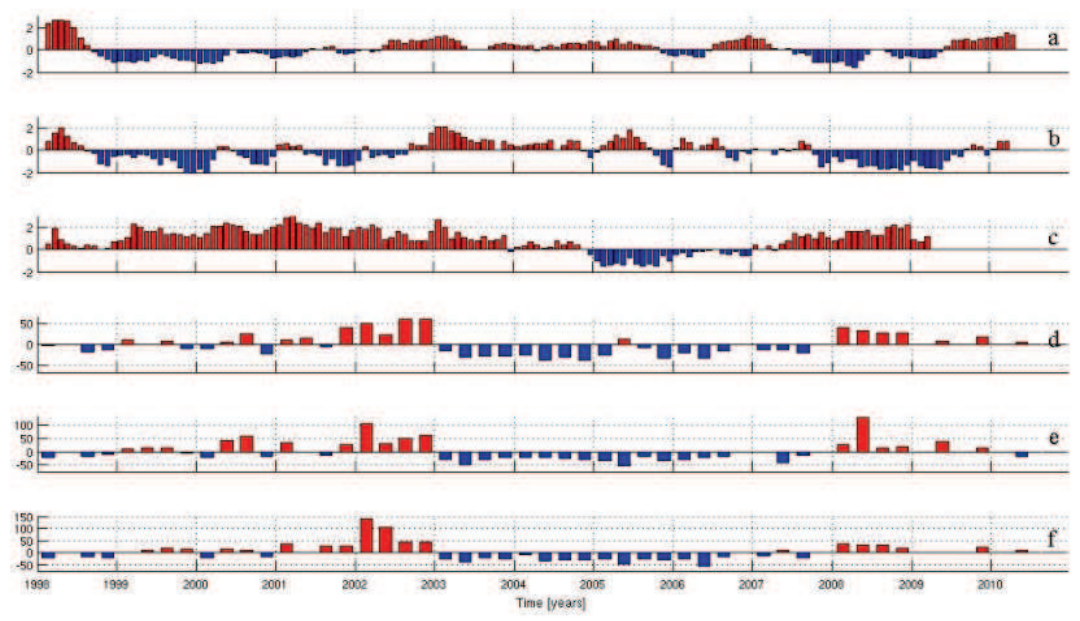

Fig. 8. Pacific Ocean climate variability indices, and water column integrated phytoplankton Chlorophyll- $a$ anomalies for three oceanic regions off Baja California described in figure 1. a) MEI (Multivariate ENSO Index); b) PDO (Pacific Decadal Oscillation); c) NPGO (North Pacific Gyre Oscillation). Water column (100 m depth) integrated Chlorophyll- $a$ anomalies calculated after removing the long-term seasonal means for the period 1998-2010. d) north region; e) central region; f) south region.

For the period 1998-2010 we calculated a positive linear relationship (correlation coefficient of 0.48 , at $95 \%$ confidence level) between NPGO index and Chlorophyll- $a$ anomalies off Baja California, without any significant differences between the Baja California regions. Interannual relationships between NPGO and chlorophyll have been reported before for the CalCOFI region (Di Lorenzo et al., 2008; http://ocean.eas.gatech.edu/npgo/), located northern Baja California. Linear relationships between water column integrated Chlorophyll- $a$ versus MEI and PDO index for the three regions were negative, with a low correlation coefficient $(\sim-0.20$, at $95 \%$ confidence level) for these two indices.

\section{Zooplankton variability}

The seasonal zooplankton biomass variability off Baja California is less remarkable related to northern sectors of the California Current System (CCS) (USGLOBEC, 1994). Following this latitudinal tendency, Baja California waters exhibits more seasonality in temperature and coastal upwelling activity in the north region $\left(30-32^{\circ} \mathrm{N}\right)$ compared to the central region $\left(24-30^{\circ} \mathrm{N}\right)$.

Considering the interannual changes, zooplankton biomass anomalies were below the 19972008 mean associated with La Niña conditions mainly in the northern region from October 1998 to April 2000 (Fig. 9). Low biomass was also associated to other interannual event known as the subarctic water intrusion, which brought to the CCS cool and low salinity water in the upper sea layer (Freeland et al., 2003; Durazo et al., 2005; Gaxiola-Castro et al., 
2008). Though the subarctic water intrusion started in July 2002, the zooplankton off Baja California response to this strong perturbation was more clearly observed by October 2002, with a dramatic reduction in zooplankton biomass. Sea surface salinity continued a decreasing tendency until February 2004, and then anomalies remained negative but stable until the end of 2006 (Lavaniegos, 2009). Zooplankton biomass during the freshening period decreased in the beginning of subarctic water intrusion, but by 2003 in the north region the zooplankton has progressively increased. In the central region the biomass rebounded until 2005. Notable increase in biomass occurred between 2005 and 2008 particularly in winter and spring, which appeared to be related to enhancement of coastal upwelling (Fig. 9).

Lavaniegos (2009) analyzed the relation of zooplankton biomass with regional (UI) and basin-scale (PDO, NPGO) proxies using multiple regression analysis. This analysis applied to data of 1997-2007 showed a significant influence of the NPGO in the variability of zooplankton biomass at both regions. In the central region UI was also significant indicating similar importance of basin and local processes.
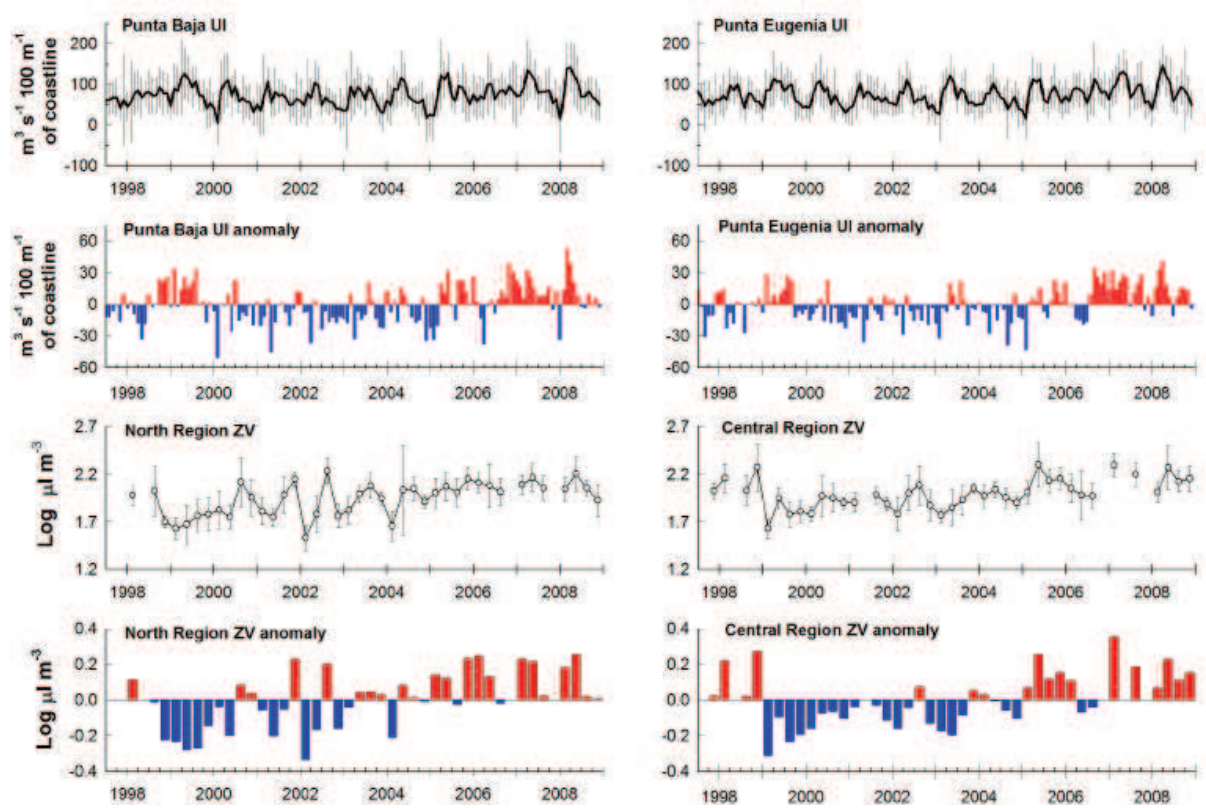

Fig. 9. Upwelling indices (UI) and zooplankton volumes (ZV) off Baja California. The UI monthly means (and standard deviations) were estimated using daily upwelling indices from www.pfeg.noaa.gov/products/products.html, in two locations (Punta Baja and Punta Eugenia). UI anomalies resulted after removing long-term monthly means from the period 1997-2008. The ZV mean for each cruise (and 95\% confidence interval) were obtained after logarithmic transformation of data grouped in two regions: north (lines 100-110) and central (lines 113-137). ZV anomalies were calculated removing long-term seasonal means from the period 1997-2008.

Zooplankton abundance diverged between regions in relation to the year season (figure 10 upper panels). By example, during summer both oceanic regions presented a long-term 
mean of 41 ind $\mathrm{m}^{-3}$. In contrast, in winter the north region has lesser zooplankton than the central region ( 28 and 39 ind $\mathrm{m}^{-3}$ long-term geometric mean respectively). It is important to bear in mind that shallow stations near the coast were excluded, where zooplankton abundance use to be from 5 to 15 times higher than oceanic waters. These stations were excluded due to high variability. Their abundance must to be estimated separately but the number of nighttime samples is low to present here precise estimations.

Copepods were more abundant in April at the north region with geometric mean of 30 ind $\mathrm{m}^{-3}$. However, they represented a higher percentage of the zooplankton in January $(65 \%)$ due to the decrease in euphausiids and other taxa. In the central region copepods were also more abundant in April and represented similar percentages in January as in April (55-56\%). The opposite tendency was observed for euphausiids which represented $8 \%$ of the total zooplankton during January in both regions (Fig. 10). The maximum contribution of euphausiids to the zooplankton community occurred in April, with $11 \%$ in the north and $15 \%$ in the central regions.

The high frequency variability make difficult to understand interannual tendencies through the period 1997-2008. Removing the seasonal variability, a long-term increase in copepods (figure 10 middle panels) and euphausiids (figure 10 lower panels) was evident in one or both oceanic regions. This increasing tendency could be promoted by increasing upwelling since 2005 to 2008 (Fig. 9).
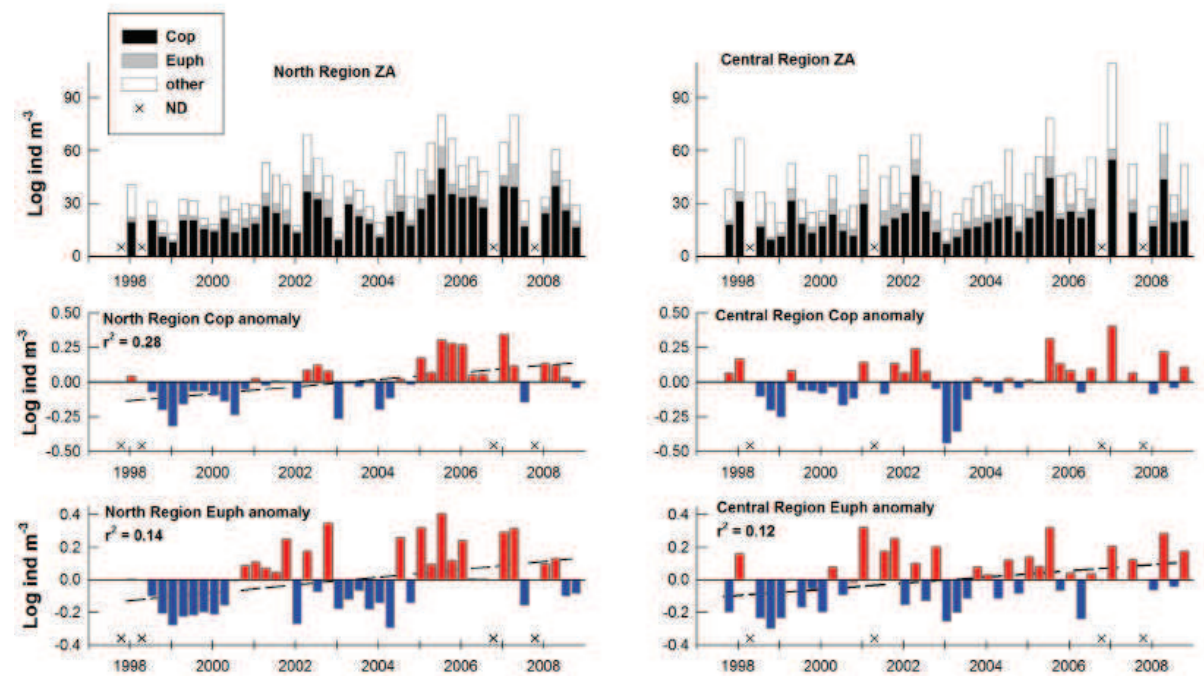

Fig. 10. Zooplankton abundance (ZA), contribution of copepods (Cop) and euphausiids (Euph) for two oceanic regions off Baja California. Stacked bars in the upper panels are geometric means of Cop, Euph, and the rest of the taxa added to obtain total zooplankton abundance. Anomalies are in logarithms and were estimated removing the long-term seasonal mean. Dashed lines are predicted values from linear regression analysis, only shown in significant cases $(\mathrm{p}<0.05)$. Data used came from nighttime samples. Cruises with no data (ND) are marked with $\underline{x}$ at the bottom of the graph. 
Abundance anomalies estimated for copepods presented a well defined tendency in the north region with an interval of negative anomalies between 1998 and 2004 followed by positive anomalies in 2005-2008. Linear regression analysis was highly significant $(F=18.0$, $\mathrm{p}<0.001)$. Euphausiids showed also a significant increase $(\mathrm{F}=8.2, \mathrm{p}=0.007)$ in the north region, but anomalies shifted above and below zero in bi-or tri-annual intervals, with negative anomalies being associated to La Niña (1998-2000), and the subarctic water intrusion (2003-2004), while the rest of the time series remained mostly positive with the notable exception of January 2002.

In the central Baja California region, the negative perturbation caused in copepod abundance by the subarctic intrusion appeared to be stronger than La Niña and this was the reason for not significant result in regression analysis despite the predominance of positive anomalies in the last three years. In contrast, negative anomalies from euphausiids associated to the subarctic perturbation were lightly weaker to those corresponding to La Niña, therefore the long-term increasing tendency resulted significant $(F=5.3, p=0.026)$. The shifting anomalies entail structural changes in the euphausiid communities (Lavaniegos \& Ambriz-Arreola, 2010). Lavaniegos (2009) found a significant relationship between crustacean herbivores (copepods + euphausiids) and the NPGO during 1997-2007 only at northern region. In the central region the relation was significant but with gelatinous herbivorous. This last also were significantly related with UI.

\section{Conclusions}

Seasonal, and interannual anomalies of wind stress, SST, SSH, CHL, and phytoplankton Chlorophyll- $a$ and zooplankton data collected during the IMECOCAL surveys off Baja California from 1997 to 2010 were examined. The analyses help to identify the influence of El Niño-La Niña cycles in the pelagic ecosystem (lower trophic level), and the strong longterm 2002-2006 effect of basin physical processes, diminishing salinity and phytoplankton biomass, and enhancing zooplankton volume.

Wind field variability off Baja California is dominated by the North Pacific high pressure center. The winds are highly persistent with south-southeast direction, favorable to coastal upwelling. During spring and summer winds are stronger and less variable than in autumnwinter, with a cyclonic curl of the wind stress over well-defined areas near the coast during the whole year. In general high wind frequencies (order of few days) play also a dominant role in the region. Wind stress on the ocean off Baja California is manifest in low sea surface temperature, and high phytoplankton production along the coast.

From the relationship of wind field off Baja California with ocean climate temporal variability, we conclude that MEI (Multivariate Enso Index) does not represent adequately the wind events in this particular coastal region, because the spatially mesoscale and local wind stress components are mainly influenced by North Pacific climate conditions, and in a less extent by the tropical and subtropical wind forcing events.

The largest part of the noteworthy sea surface temperature (SST) variability events off Baja California occur during 1997-1998, 2004 and 2006, consequent of El Niño conditions, with both MEI and sea surface temperature (SST) showing positive anomalies. Negative SST anomalies occurred during 2002-2003 related with positive MEI values. In general, SST negatives anomalies were manifest during La Niña phase, mainly between winter 1998 and 2000-2001, and continue until 2003. Sea Surface Height (SSH) anomalies were well connected 
with MEI, with the exception during La Niña conditions (1999-2000). Throughout La Niña 1999-2000 the MEI and SST showed negative values, while SSH was positive, which is not consistent with a thermal oceanic expansion.

Satellite chlorophyll time series described the influence of El Niño-La Niña cycles off Baja California, with different responses for central and southern regions. Phytoplankton Chlorophyll- $a$ positive anomalies were associated with a cold period, characterized by negative anomalies of the Pacific Decadal Oscillation (PDO index), with a warm phase of this index from summer 2002 to at least summer 2006, differentiated by negative Chlorophyll- $a$ anomalies off Baja California. After 2006, PDO index shows more neutral or negative values, defining the beginning of a cool phase (2007-2008), with positive anomalies of phytoplankton biomass off Baja California. Following 2007 a shift to a cool ocean climate phase appears to be present in the region, revealed by strong negative values of the PDO index, similar to those obtained by 2001 and early 2002. Nevertheless those changes off Baja California are observed as positive anomalies of salinity and zooplankton biomass (mainly salps), they are not apparent in phytoplankton positive anomalies.

Phytoplankton Chlorophyll- $a$ linear relationships were mainly related with NPGO (North Pacific Gyres Oscillation) index, without any significant relationship with MEI and PDO indices. Perhaps, the increase in phytoplankton growth off Baja California during some times of the 1998-2010 events was influenced by changes in surface circulation of the northeast Pacific Ocean, which in turn respond to North Pacific climate forcing. From longterm Pacific Ocean climate index (MEI, PDO, and NPGO) and Chlorophyll- $a$ anomalies trends, this is not very apparent that the IMECOCAL subdivided regions response differently to physical forcing, in spite of the domains identified by hydrologic ocean properties. Nevertheless, zooplankton biomass differences are reflected in these provinces (north and central regions) related to the year season, through contrasting responses to large scale events and local coastal upwelling processes. According our data set from 1997-2008, NPGO index showed a significant influence of the variability of zooplankton biomass at both regions (northern and central).

\section{Future research}

In order to have a better understanding of the pelagic ecosystem response off Baja California to ocean climate variability, analyses of main phytoplankton groups and their relationship with a more accurate and regional ocean index are necessary. Also, these phytoplankton assemblages could be related with the main constituent of zooplankton groups, to understand food web transference in the IMECOCAL region, and their relation with local and large spatially physical processes. For instance, a first step in this direction is to generate a regional ocean climate variability index for Baja California waters.

The effect of the wind stress curl on the pelagic ecosystem is other of the topics to be revisited for the region off Baja California. Because of the wind stress curl and sea surface temperature relationships, this parameter could have a relation with plankton variability in the oceanic waters off Baja California.

There are preliminary indications of a colder tendency in the California Current System, based on long-term sea surface temperature analyses. If this trend is correct, we will expect an increase in the lower trophic organism's biomass off Baja California for the next years. In this chapter, merely some of the zooplankton groups (Copepods and Euphausiids) have 
been shown a similar tendency, and only for the northern region, mainly influenced by subarctic waters. More research we need to realize in this direction to understand the effect of long-term climate variability on the pelagic marine ecosystems, mainly on plankton abundance and biomass changes.

\section{Acknowledgements}

Thanks are given to students, technicians, researchers, and crew of $R / V$ Francisco de Ulloa working on the IMECOCAL cruises. Special thanks to J.L. Cadena-Ramírez \& P. GarcíaGarcía for assistance in zooplankton counting, and to S. Nájera-Martínez \& M.E. De la CruzOrozco working with chlorophyll analyses. The altimeter products were produced by Ssalto/Duacs and distributed by AVISO, with support from Cnes (http://www.aviso.oceanobs.com/duacs/). Sea Surface Temperature (SST) was obtained from the site ftp://podaac.jpl.nasa.gov/pub/sea_surface_temperature/avhrr/pathfinder. The wind product was obtained from ftp://podaac.jpl.nasa.gov/ocean_wind/ccmp/L3.0/. We would like to thanks the responsible of all satellite products. This research was supported with grants from the Mexican Council of Science and Technology (CONACYT: G0041T, 017Pñ-1297, G35326T, C0125343, C02-42569, 47044, 23947, 48367, SEMARNATCONACYT 23804), and by SIP-IPN 20090831. We are grateful with CICESE (Centro de Investigación Científica y de Educación Superior de Ensenada, México) for its IMECOCAL Program support, and the facilities of the $R / V$ Francisco de Ulloa, together with funds from special research projects.

\section{References}

Atlas, R.; Hoffman, R.N., Bloom, S.C., Jusem, J.C. \& Ardizzone, J. (1996). A multiyear global surface wind velocity data set using SSM/I wind observations. Bulletin American Meteorology Society, 77, 869-882.

Bograd, S.J.; DiGiacomo, P.M., Durazo, R., Hayward, T.L., Hyrenbach, K.D., Lynn, R.J., Mantyla, A.W., Schwing, F.B., Sydemna, W.J., Baumgartner, T., Lavaniegos, B. \& Moore, C.S. (2000). The State of the California Current, 1999-2000: Forward to a New Regime?. California Cooperative Oceanic Fisheries Investigations Reports, 41, 26-52, 0575-3317.

Bograd, S.J. \& Lynn, R.J. (2003). Anomalous subarctic influence in the southern California Current during 2002. Geophysical Research Letters, 30, 15, 8020, doi:10.1029/2003GL017446.

Cappet, X.J.; Marchesiello, P. \& McWilliams, J.C. (2004). Upwelling response to coastal wind profiles. Geophysical Research Letters, 13, L13311, doi: 10.1029/2004GL020123.

Casey, K.S. \& Adamec, D. (2002). Sea surface temperature and sea surface height variability in the North Pacific Ocean from 1993 to 1999. Journal of Geophysical Research, 107, C8, 10.1029/2001JC001060.

Castro, R. \& Martínez, J.A. (2010). Spatial and temporal wind field variability. In: Dynamic of the Pelagic Ecosystem off Baja California, 1997-2007. Gaxiola-Castro, G. \& Durazo, R. (Eds.). INE, CICESE, UABC. Mexico. (In Spanish). 
Chelton, D.B.; Schlax, M.G. \& Samelson, R.M. (2007). Summertime coupling between sea surface temperature and wind stress in the California Current System. Journal of Physical Oceanography, 37, 495-517.

Di Lorenzo, E.; Schneider, N., Cobb, K.M., Chhak, K., Franks, P. J. S., Miller, A. J., McWilliams, J. C., Bograd, S.J., Arango, H., Curchister, E., Powell, T. M. \& Rivere, P. (2008). North Pacific Gyre Oscillation links ocean climate and ecosystem change. Geophysical Research Letters, 35, L08607, doi:10.1029/2007GL032838.

Durazo, R. \& Baumgartner, T. (2002). Evolution of oceanographic conditions off Baja California: 1997-1999. Progress in Oceanography, 54, 7-31.

Durazo, R.; Gaxiola-Castro, G., Lavaniegos, B.E., Castro-Valdéz, R., Gómez-Valdés, J. \& Mascarenhas Jr., A.S. (2005). Oceanographic conditions west of the Baja California coast, 2002-2003: a weak El Niño and subarctic water enhancement. Ciencias Marinas, 31, 3, 537-552, 0185-3880.

Durazo, R. (2009). Climate and upper ocean variability off Baja California, Mexico: 19972008. Progress in Oceanography, 83, 361-368, doi:10.1016/j.pocean.2009.07.043.

Espinosa-Carreón T.L.; Strub, P.T., Beier, E., Ocampo-Torres, F. \& Gaxiola-Castro, G. (2004). Seasonal and interannual variability of satellite derived chlorophyll pigment, surface height, and temperature off Baja California. Journal of Geophysical Research, 109, C03039, doi:10.1029/2003JC0020105.

Freeland, H.J.; Gatien, G., Huyer, A. \& Smith, R.L. (2003). Cold halocline in the northern California Current: an invasion of subarctic water. Geophysical Research Letterrs, 30, 3, 1141. doi:10.1029/2002GL016663.

Gaxiola-Castro, G.; Durazo, R., Lavaniegos, B., De-la-Cruz-Orozco, M.E., Millán-Nuñez, E., Soto-Mardones, L. \& Cepeda-Morales, J. (2008). Pelagic ecosystem response to interannual variability off Baja California. Ciencias Marinas, 34, 2, 263-270, 0185-3880.

Holm Hansen, O.; Lorenzen, C., Holmes, R. \& Strickland, J. (1965). Fluorometric determination of chlorophyll. J. Cons. Perm. Int. Explor. Mer, 30, 3-15.

Hoffman, R.N. (1984). SASS wind ambiguity removal by direct minimization. Part II: Use of smoothness and dynamical constraints. Monthly Weather Review, 112, 1829-1852.

Huyer, A. (1983). Coastal upwelling in the California Current System. Progress in Oceanography, 12, 259-284.

Kahru, M. \& Mitchell, B.G. (2000). Influence of the 1997- 98 El Niño on the surface chlorophyll in the California Current. Geophysical Research Letters 27, 2937-2940, 0094-8276.

Lavaniegos, B.E. (2009). Influence of a multiyear event of low salinity on the zooplankton from Mexican eco-regions of the California Current. Progress in Oceanography, 83, 369-375.

Lavaniegos, B.E.; Ambriz-Arreola, I., Hereu, C.M., Jiménez-Pérez, L.C., Cadena-Ramírez, J.L. \& García-García, P. (2010). Seasonal and interannual zooplankton variability. In: Dynamic of the Pelagic Ecosystem off Baja California, 1997-2007. Gaxiola-Castro, G. \& Durazo, R. (Eds.). INE, CICESE, UABC. Mexico. (In Spanish).

Lavaniegos, B.E. \& Ambriz-Arreola, I. (2010). Interannual variability in krill off Baja California in the period 1997-2005. Progress in Oceanography (submitted).

Leuliette, E.W. \& Wahr, J.M. (1999). Coupled pattern analysis of sea surface temperature and TOPEX/Poseidon sea surface height. Journal of Physical Oceanography, 29, 599-611. 
Lynn, R.J.; Bumgartner, T., Garcia, J., Collins, C.A., Hayward, T.L., Hyrenbach, K.D., Mantyla, A.W., Murphree, T., Shankle, A., Schwing, F.B., Sakuma, K.M. \& Tegner, M.J. (1998). The State of the California Current, 1997-1998: transition to El Niño Conditions. California Cooperative Ocenaic Fisheries Investigations Reports, 39, 25-49, 0575-3317.

McClatchie, S.; Goericke, R., Schwing, F.B., Bograd, S.J., Peterson, W.T., Emmett, R., Charter, R., Watson, W., Lo, N., Hill, K., Collins, C., Kahru, M., Mitchell, B.G., Koslow, J.A., Gomez-Valdes, J., Lavaniegos, B.E., Gaxiola-Castro, G., Gottschalck, J., L'Heureux, M., Xue, Y., Manzano-Sarabia, M., Bjorkstedt, E., Ralston, S., Field, J., RogersBennett, L., Munger, L., Campbell, G., Merkens, K., Camacho, D., Havron, A., Douglas, A. \& Hildebrand, J. (2009). The State of the California Current, spring 2008-2009: Cold conditions drive regional differences in coastal production. California Cooperative Fisheries Investigations Reports, 50, 43-68, 0575-3317.

Perez-Brunius, P.; Lopez M., Pares-Sierra, A. \& Pineda, J. (2007). Comparison of upwelling indices off Baja California derived from three different wind data sources. California Cooperative Oceanic Fisheries Investigations Reports, 48, 204-214, 0575-3317.

Peterson, P.T. \& Schwing, F.B. (2003). A new climate regime in northeast Pacific ecosystems. Geophysical Research Letters, 30, 17, doi:10.1029/2003GL017528.

Schwing, F.B.; Bograd, S.J., Collins, C.A., Gaxiola-Castro, G., Garcia, J., Goericke, R., GomezValdes, J., Huyer, A., Hyrenbach, K.D., Kosro, P.M., Lavaniegos, B.E., Lynn, R.J., Mantyla, A.W., Ohman, M.D., Peterson, W.T., Smith, R.L., Sydeman, W.J., Venrick, E. \& Wheeler, P.A. (2002). The State of the California Current, 2001-2002: will the California Current System keep cool, or is El Niño looming?. California Cooperative Oceanic Fisheries Investigations Reports, 43, 31-68, 0575-3317.

Strub, P.T.; Allen, J.S., Huyer, A., Smith, R.L. \& Beardsley, R.C. (1987). Seasonal cycles of currents, temperatures, winds, and sea level over the northeast Pacific continental shelf: $35^{\circ} \mathrm{N}$ to $48^{\circ} \mathrm{N}$. Journal of Geophysical Research, 92, C2, 1507-1526.

Strub, P.T. \& James, C. (2002). Altimeter-derived surface circulation in the large-scale NE Pacific gyres: Part 1. Seasonal variability. Progress in Oceanography, 53, 163-183.

US GLOBEC (1994). A science plan for the California Current. United States GLOBEC Ocean Ecosystem Dynamics, Report 11, Department of Integrative Biology, University of California, Berkeley, California, $124 \mathrm{p}$.

Venrick, E. \& Hayward, T.L. (1984). Determining chlorophyll on the 1984 CalCOFI surveys. California Cooperative Oceanic Fisheries Investigations Reports, 25, 74-79, 0575-3317.

Yentsch, C.S. \& Menzel, D.W. (1963). A method for the determination of phytoplankton chlorophyll and phaeophytin by fluorescence. Deep-Sea Research, 10, 221-231.

Yoder, J. A. \& Kennelly, M. A. (2003). Seasonal and ENSO variability in global ocean phytoplankton chlorophyll derived from 4 years of Sea-WiFS measurements. Global Biogeochemical Cycles 17, 4, 1112, doi:10.1029/2002GB001942, 0886-6236. 


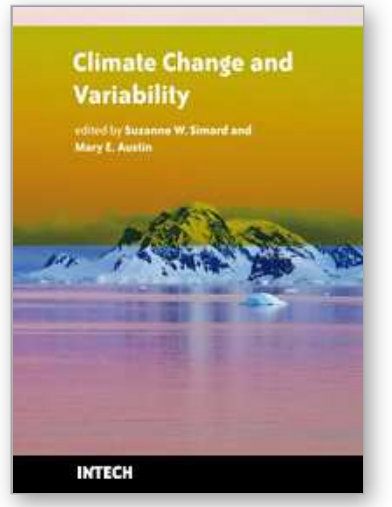

\author{
Climate Change and Variability \\ Edited by Suzanne Simard
}

ISBN 978-953-307-144-2

Hard cover, 486 pages

Publisher Sciyo

Published online 17, August, 2010

Published in print edition August, 2010

Climate change is emerging as one of the most important issues of our time, with the potential to cause profound cascading effects on ecosystems and society. However, these effects are poorly understood and our projections for climate change trends and effects have thus far proven to be inaccurate. In this collection of 24 chapters, we present a cross-section of some of the most challenging issues related to oceans, lakes, forests, and agricultural systems under a changing climate. The authors present evidence for changes and variability in climatic and atmospheric conditions, investigate some the impacts that climate change is having on the Earth's ecological and social systems, and provide novel ideas, advances and applications for mitigation and adaptation of our socio-ecological systems to climate change. Difficult questions are asked. What have been some of the impacts of climate change on our natural and managed ecosystems? How do we manage for resilient socio-ecological systems? How do we predict the future? What are relevant climatic change and management scenarios? How can we shape management regimes to increase our adaptive capacity to climate change? These themes are visited across broad spatial and temporal scales, touch on important and relevant ecological patterns and processes, and represent broad geographic regions, from the tropics, to temperate and boreal regions, to the Arctic.

\title{
How to reference
}

In order to correctly reference this scholarly work, feel free to copy and paste the following:

Gilberto Gaxiola-Castro (2010). Pelagic Ecosystem Response to Climate Variability in the Pacific Ocean off Baja California, Climate Change and Variability, Suzanne Simard (Ed.), ISBN: 978-953-307-144-2, InTech, Available from: http://www.intechopen.com/books/climate-change-and-variability/pelagic-ecosystem-responseto-climate-variability-in-the-pacific-ocean-off-baja-california

\section{INTECH}

open science | open minds

\author{
InTech Europe \\ University Campus STeP Ri \\ Slavka Krautzeka 83/A \\ 51000 Rijeka, Croatia \\ Phone: +385 (51) 770447 \\ Fax: +385 (51) 686166 \\ www.intechopen.com
}

\author{
InTech China \\ Unit 405, Office Block, Hotel Equatorial Shanghai \\ No.65, Yan An Road (West), Shanghai, 200040, China \\ 中国上海市延安西路65号上海国际贵都大饭店办公楼 405 单元 \\ Phone: +86-21-62489820 \\ Fax: +86-21-62489821
}


(C) 2010 The Author(s). Licensee IntechOpen. This chapter is distributed under the terms of the Creative Commons Attribution-NonCommercialShareAlike-3.0 License, which permits use, distribution and reproduction for non-commercial purposes, provided the original is properly cited and derivative works building on this content are distributed under the same license. 